\title{
SENTRALISASI LISENSI PERANGKAT LUNAK DAN INTERKONEKSI DATA
}

\author{
Arnazt P. Adryanto, Bronto Sutopo, Febri E. Prihasto, Arif Hindarto, Duduk Sumargono \& Ansori
}

PT ANTAM Tbk, GEOMIN - Unit Eksplorasi, Jakarta, Indonesia

\begin{abstract}
ABSTRAK
Industri 4.0 adalah istilah yang diberikan untuk industri "pintar" dimana mesin/perangkat digabung dengan koneksi jaringan. Tren industri 4.0 adalah otomatisasi dan koneksivitas data termasuk cloud computing. Sekarang, dan masa mendatang di industri 4.0, komputer terhubung satu sama lain untuk akhirnya membuat keputusan tanpa keterlibatan manusia. Industri pertambangan merupakan salah satu industri yang paling membutuhkan koneksi karena lokasi site terpisah dengan head office. Sebagai pelaku industri pertambangan yang memiliki site lebih dari satu dan tersebar dari Indonesia bagian Barat sampai dengan bagian Timur, PT ANTAM Tbk (ANTAM) memerlukan koneksi antara site dengan head office. Salah satu rangkaian pekerjaan ANTAM adalah collecting database eksplorasi, pemodelan geologi dan estimasi sumberdaya serta distribusi block model sumberdaya ke site. Database eksplorasi tersebut digunakan untuk update model geologi dan estimasi sumberdaya setiap triwulan semua komoditas dari tiap site yang sedang aktif kegiatan eksplorasinya. Lisensi software-software yang digunakan oleh ANTAM untuk pemodelan dan estimasi sumberdaya tersebut terpusat di server di head office, sehingga tidak ada lisensi software yang standalone di computer user. Hal tersebut membuat siapapun dandimanapun lokasinya bisa menggunakan lisensi-lisensi yang tersedia dengan koneksi ke server. Hasil update block model sumberdaya kemudian di distribusikan ke site sebagai guidance. Tim di site juga melakukan pengolahan terhadap block model tersebut menggunakan software tertentu dengan lisensi yang tersedia di server melalui koneksi internal ANTAM dari site ke head office di Jakarta. Meskipun dalam pengolahan update block model sumberdaya tidak seluruhnya otomatis, karena masih memerlukan justifikasi resource estimator atau Competent Person, namun dalam pengerjaannya bisa kapanpun dan dimanapun karena lisensi yang terpusat dan dapat digunakan oleh siapapun yang memerlukan. Sentralisasi lisensi perangkat lunak dan interkoneksi data yang dilakukan oleh ANTAM membuat distribusi data eksplorasi dan update block model sumberdaya tiap komoditas ANTAM yang tersebar dari Indonesia bagian Barat sampai bagian Timur tidak terkendala jarak dan waktu, khususnya untuk update block model. Hal tersebut dapat dilakukan kapanpun dan dimanapun, serta siapapun yang memerlukan dapat menggunakan lisensi software yang tersedia di server.
\end{abstract}

Key words: industri 4.0, koneksivitas, lisensi, server, database eskplorasi, block model sumberdaya

\begin{abstract}
Industry 4.0 is a name given to the idea of smart industry where machines are augmented with the web connectivity. The trend is towards automation and data connectivity includes cloud computing. Now, and into the future as Industry 4.0 unfolds, computers are connected and communicate with one another to ultimately make decisions without human involvement. Mining industry is one of industry that really needs connectivity because the location of site is separate to its head office. As a mining industry with more than one of sites that spread from west part to east part of Indonesia, PT ANTAM Tbk (ANTAM) needs connectivity between sites and head office. One of working cycle of ANTAM is exploration database collecting, geological modeling, resource estimation and distribution the resource block model to sites. The exploration database will be used to update the geological model and estimate the resources every quarter for each commodity of each site which is actively explore. The licenses of ANTAM's software to do modeling and estimate the resources
\end{abstract}


are centralized in a server in head office, so there is no standalone software license in user computer. Centralized licenses make anyone and everywhere can utilize the licenses using connection to the server. The updated block model distributed to sites as guidance. Team on sites work on the block model use certain software with licenses that centralized in the server through ANTAM's connection from sites to head office. Although in estimate the resources not fully automation due to still need justification from resource estimator or Competent Person, but in the process could be everywhere and anytime because of centralized licenses. Centralized software licenses and data interconnection of ANTAM make distribution of exploration data and updated block model for each commodities of ANTAM that spread from west part to east part of Indonesia is not a problem, especially for updating the block model. It could be proceed everywhere, anytime by everyone using licenses in the server.

Key words: industry 4.0, connectivity, license, server, exploration database, resource block model

\section{A. PENDAHULUAN}

Revolusi industri adalah perubahan besar terhadap cara manusia dalam mengolah sumberdaya alam dan memproduksi barang. Sampai dengan sekarang, dunia telah mengalami tiga revolusi dalam dunia industri yang terjadi pada abad 18 sampai 20. Pada abad 18 adalah revolusi industri pertama menghasilkan mekanisasi dengan ditemukannya mesin uap, sedangkan revolusi yang kedua dan ketiga terjadi pada abad 20 menghasilkan produksi masal dan otomatisasi dalam produksi. Dan saat ini telah mulai revolusi keempat atau dikenal dengan istilah indutri 4.0. Industri 4.0 adalah istilah yang diberikan untuk industri "pintar" dimana mesin/perangkat digabung dengan koneksi jaringan. Tren industri 4.0 adalah otomatisasi dan koneksivitas data termasuk cloud computing. Sekarang, dan masa mendatang di industri 4.0, komputer terhubung satu sama lain untuk akhirnya membuat keputusan tanpa keterlibatan manusia. Gambar 1 adalah perubahan industry dari revolusi pertama sampai dengan keempat.

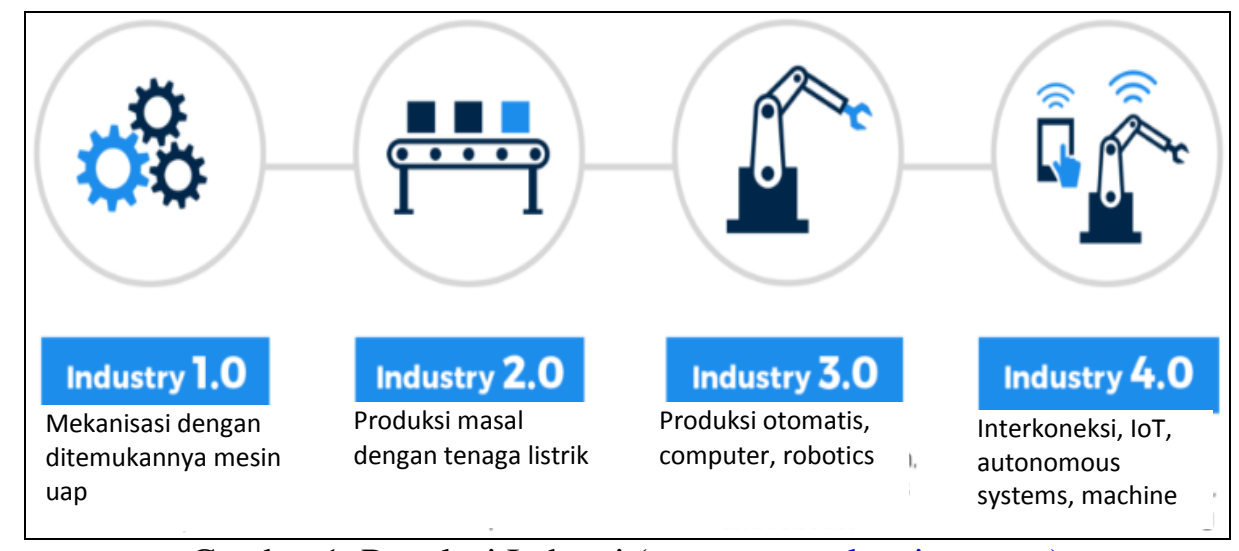

Gambar 1. Revolusi Industri (www.spectralengines.com)

Pada Gambar 1 dapat dilihat bahwa industri 4.0 salah satu kriterianya adalah mengandalkan koneksi (IoT / Internet of Things). Industri pertambangan merupakan salah satu industri yang paling membutuhkan koneksi karena pada umumnya lokasi site terpisah dengan head office. PT ANTAM Tbk (ANTAM) memiliki lokasi site yang tersebar dari Indonesia bagian Barat sampai Timur dengan tiga jenis komoditas (Gambar 2). Site komoditas emas berada di Jawa Barat dan Banten, bauksit berada di Kalimantan Barat, dan nikel berada di Sulawesi Tenggara dan Halmahera Timur, sedangkan head office ANTAM berada di Jakarta. Jarak antara head office dan site antara $120 \mathrm{~km}$ untuk site terdekat sampai dengan $2.400 \mathrm{~km}$ untuk site terjauh. 


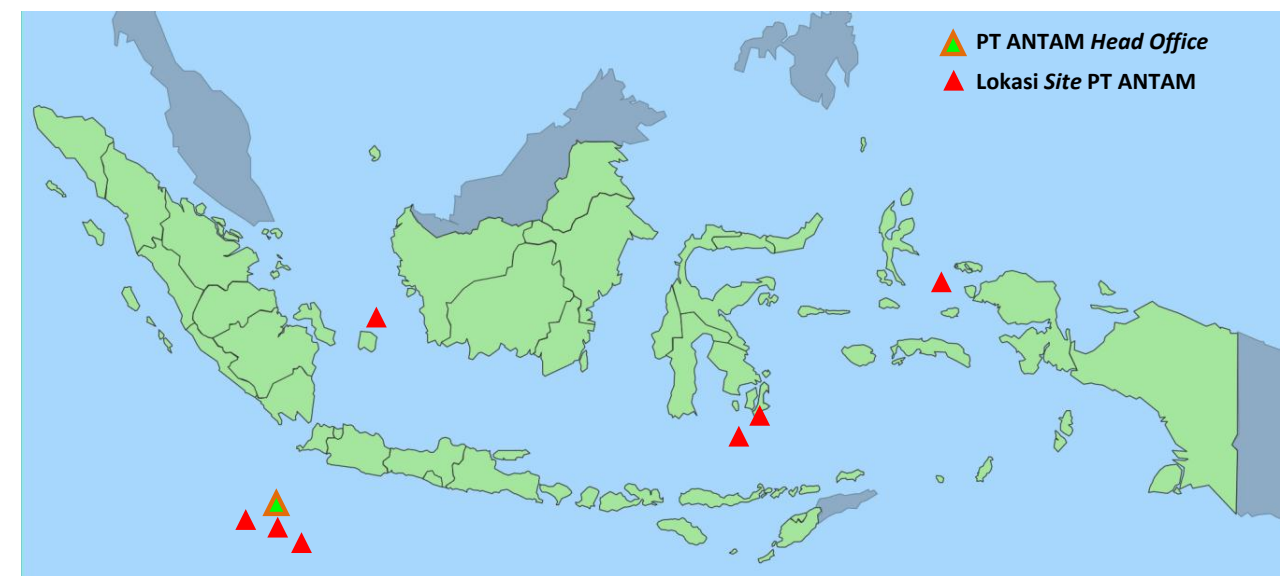

Gambar 2. Lokasi Head Office dan Site ANTAM

\section{B. RANGKAIAN DAN LINGKUNGAN KERJA PT ANTAM}

Rangkaian pekerjaan di ANTAM salah satunya adalah collecting database eksplorasi, pemodelan geologi dan estimasi sumberdaya serta distribusi block model sumberdaya ke site (Gambar 3). Collecting database dilakukan oleh tim eksplorasi di tiap site. Kegiatan eksplorasi yang dilakukan pada umumnya adalah pengeboran, baik itu untuk mendetilkan atau mendapatkan potensi yang lain dari tiap komoditas. Semua database eksplorasi disimpan di server yang berada di head office oleh tim eksplorasi secara rutin setiap akhir bulan (Gambar 4).

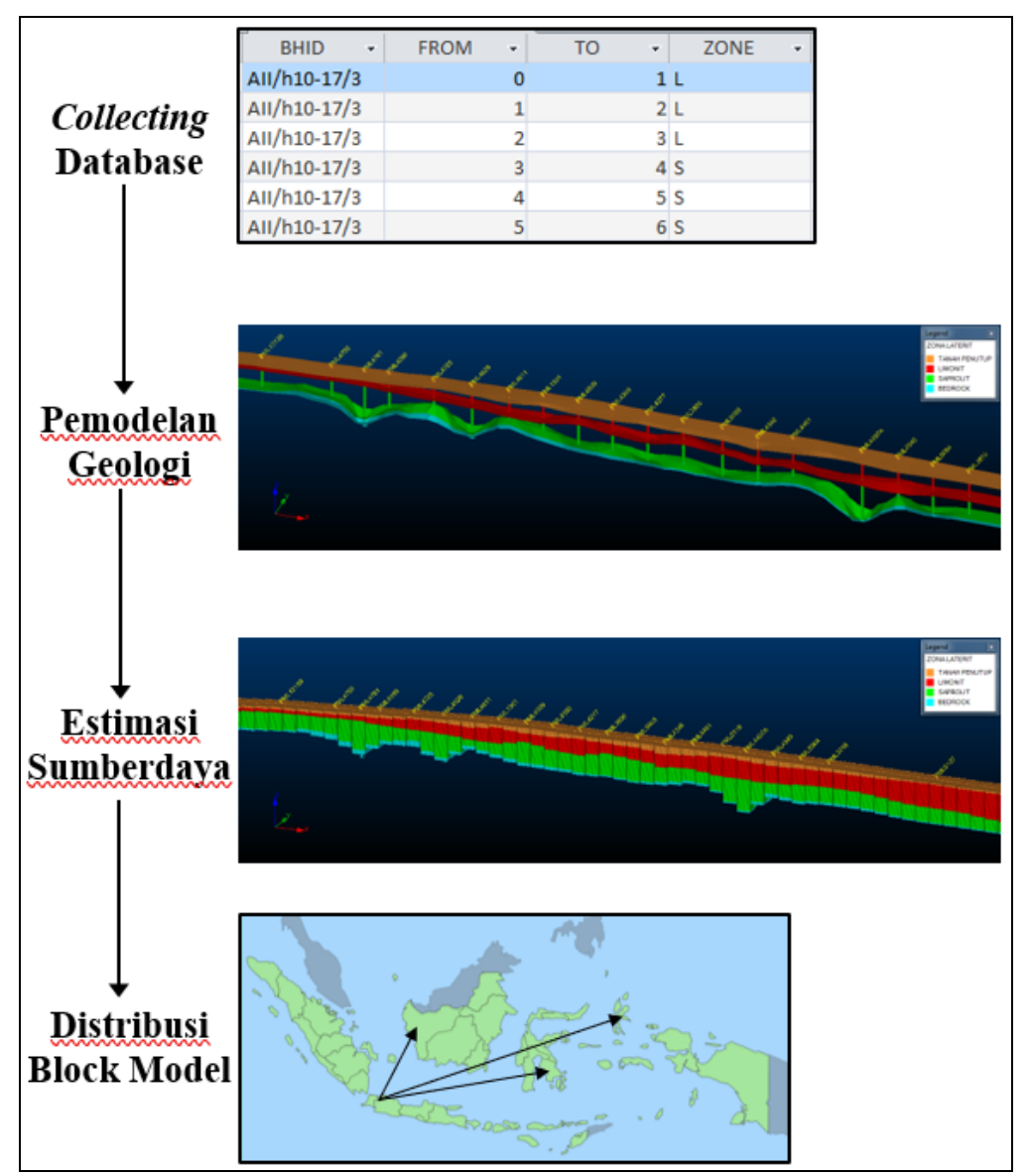

Gambar 3. Rangkaian Pekerjaan Eksplorasi Sampai Dengan Distribusi Block Model Sumberdaya 


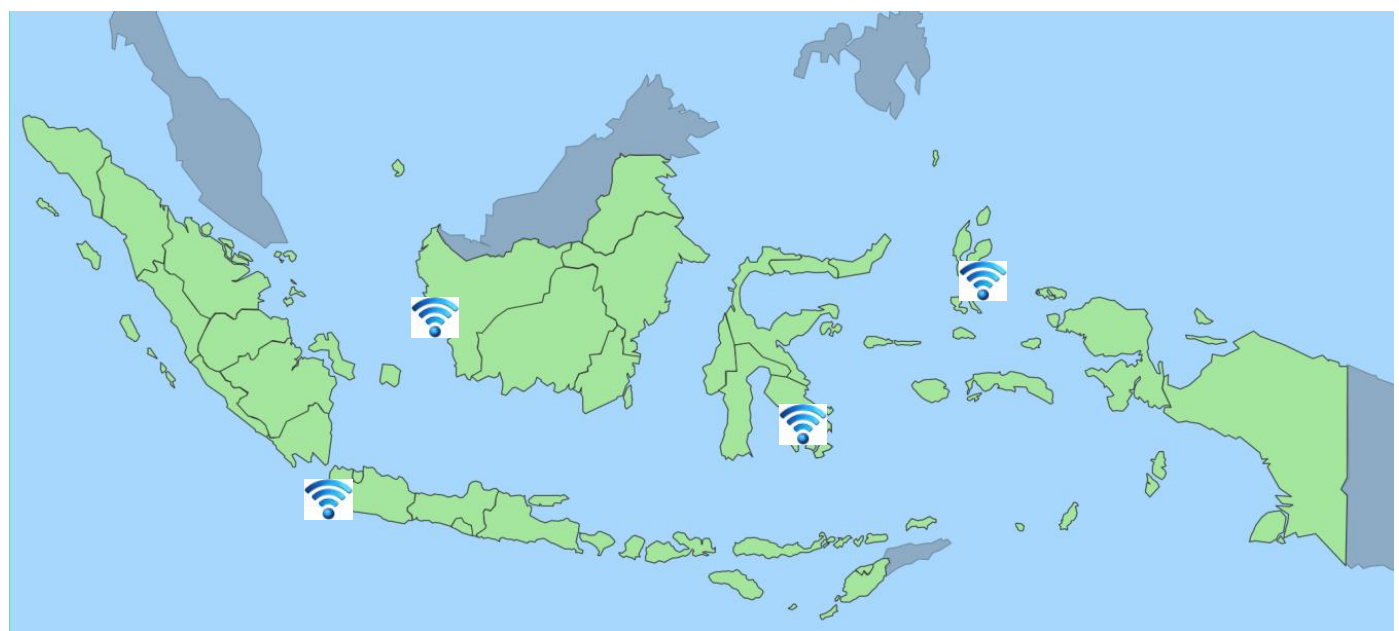

Gambar 4. Koneksi Site Dengan Server Di Head Office

Database bor eksplorasi yang sudah disimpan di server diolah di head office. Data bor tersebut diolah menjadi model geologi dan estimasi perolehan sumberdaya setiap triwulan untuk monitoring pencapaian target perusahaan setiap tahun. Meskipun pengolahan data eksplorasi pada dasarnya dilakukan di head office, namun lingkungan kerjanya relative mobile dan lokasi site-nya juga tersebar, dimana untuk melakukan pengolahan data di lingkungan kerja yang mobile dan site yang tersebar memerlukan perangkat lunak yang juga "mobile" (Gambar 5), namun tetap terjaga keamanan asset perangkat lunak tersebut.

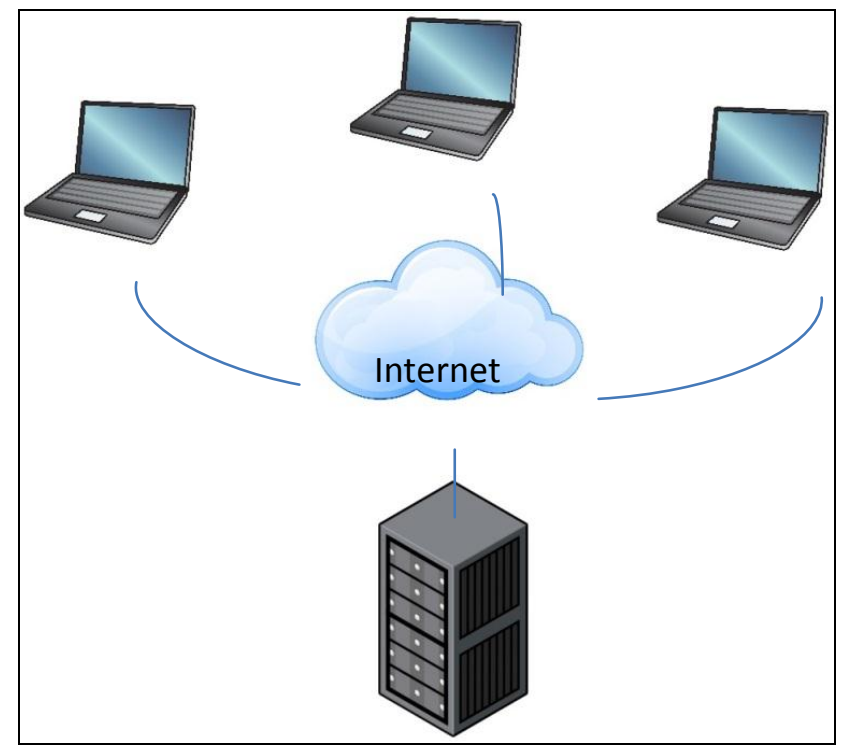

Gambar 5. Ilustrasi Perangkat Lunak "Mobile"

\section{KONEKSIVITAS LISENSI DAN DATA}

Gambaran rangkaian dan lingkungan kerja di ANTAM tersebut mengindikasikan sangat diperlukannya koneksi dan keamanan terhadap data dan perangkat lunak. Sistem yang dipakai sebelum penerapan sentralisasi lisensi perangkat lunak dan interkoneksi data adalah menggunakan server-server lokal di tiap lokasi dan lisensi perangkat lunak juga tersebar di tiap lokasi. Sistem tersebut dipakai pada saat itu karena memang koneksi (IoT) yang dimiliki masih terbatas kemampuannya, sehingga tidak efisien karena banyak kendala. Kendala yang dihadapi adalah masalah koneksivitas database dan keamanan lisensi perangkat lunak. Database tersimpan di server-server lokal di tiap site dan di head office, sehingga pengelompokan datanya di tiap server 
berbeda-beda, selain itu memungkinkan terdapat perbedaan versi database antara tiap server karena terdapat jeda waktu untuk update database diantara server yang berbeda-beda. Keamanan lisensi juga rentan terhadap kehilangan dongle perangkat lunak. Dengan kesadaran pentingnya koneksivitas data dan keamanan aset perangkat lunak, maka secara bertahap dibangun sistem yang centralized dengan meningkatkan kemampuan koneksi di internal ANTAM.

Seiring meningkatnya kemampuan koneksi ANTAM maka sistem tersebut juga berubah. Sistem yang sudah dibangun dengan meningkatnya kemampuan koneksi adalah sentralisasi lisensi perangkat lunak dan interkoneksi data. Sentralisasi lisensi perangkat lunak adalah suatu sistem dimana semua lisensi perangkat lunak dikumpulkan di dalam satu server sehingga tidak ada lisensi yang standalone di satu komputer saja. Lokasi server tersebut berada di head office, sedangkan user lisensi tersebar di semua site. Gambar 6 adalah perubahan sistem lisensi perangkat lunak ANTAM seiring dengan waktu.

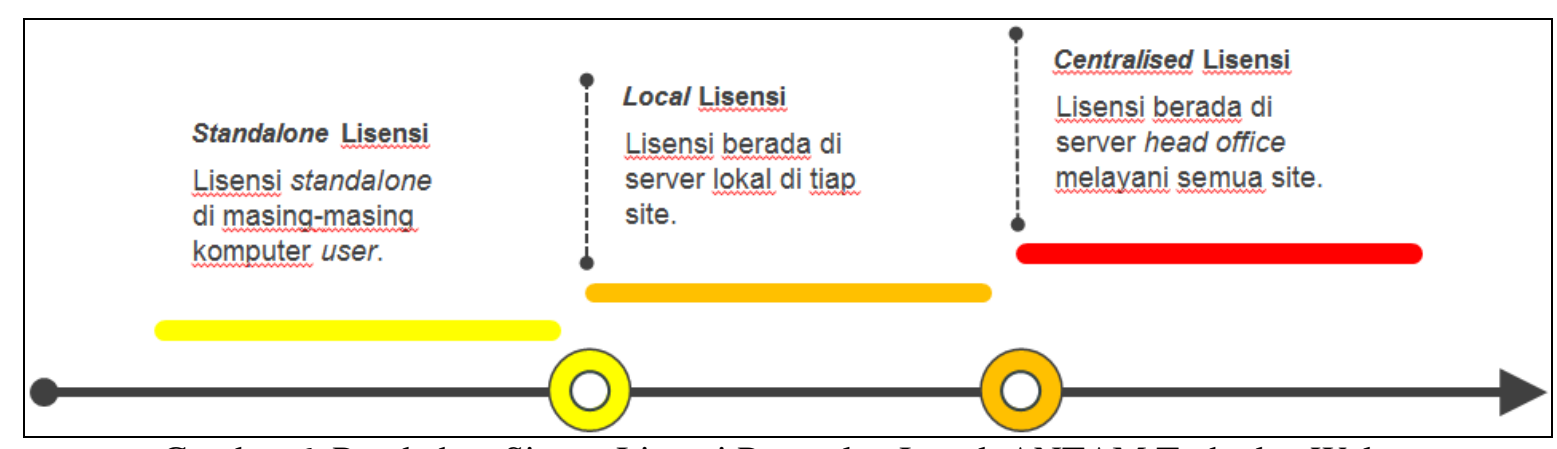

Gambar 6. Perubahan Sistem Lisensi Perangkat Lunak ANTAM Terhadap Waktu

Pada Gambar 6 dapat dilihat perubahan sistem lisensi di ANTAM. Dimulai dari lisensi perangkat lunak yang standalone di tiap komputer berubah menjadi lisensi berada di sever lokal dan terakhir adlah lisensi perangkat lunak dipusatkan di server head office. Lisensi perangkat lunak yang terpusat di server head office berarti dongle perangkat lunak tetap di head office sehingga menghindari kehilangan dongle jika dongle tersebut berada di komputer user, namun sistem tersebut bukan berarti membatasi mobilitas penggunaan perangkat lunak. Sistem tersebut justru meningkatkan mobilitas penggunaan perangkat lunak, meningkatkan fleksibilitas pemakai perangkat lunak, dan meningkatkan keamanan perangkat lunak yang merupakan aset ANTAM.

Meningkatkan mobilitas karena sistem tersebut memungkinkan user untuk mengambil lisensi meskipun berada di site yang lokasinya jauh dari head office. Meningkatkan fleksibilitas pemakai perangkat lunak karena lisensi tidak dedicated untuk satu user dan yang paling penting adalah keamanan dongle perangkat lunak menjadi terjamin dari resiko hilang karena dongle tetap berada di head office.

Pekerjaan update block model sumberdaya pun dapat dilakukan dimana saja dan kapanpun, meskipun tidak semua langkah-langkah update block model sumberdaya dilakukan secara otomatis karena masih diperlukan justifikasi oleh resource estimator atau Competent Person.

Interkonekasi data juga merupakan sistem yang dibangun dengan meningkatnya kemampuan koneksi ANTAM. Interkoneksi data memiliki konsep yang sama dengan sentralisasi lisensi hanya penggunaannya berbeda. Interkoneksi data juga menggunakan server yang terpusat di head office, dimana server tersebut juga terhubung dengan server-server lokal yang ada di tiap site. Gambar 7 adalah perubahan koneksi data antara site dengan head office seiring dengan waktu. 


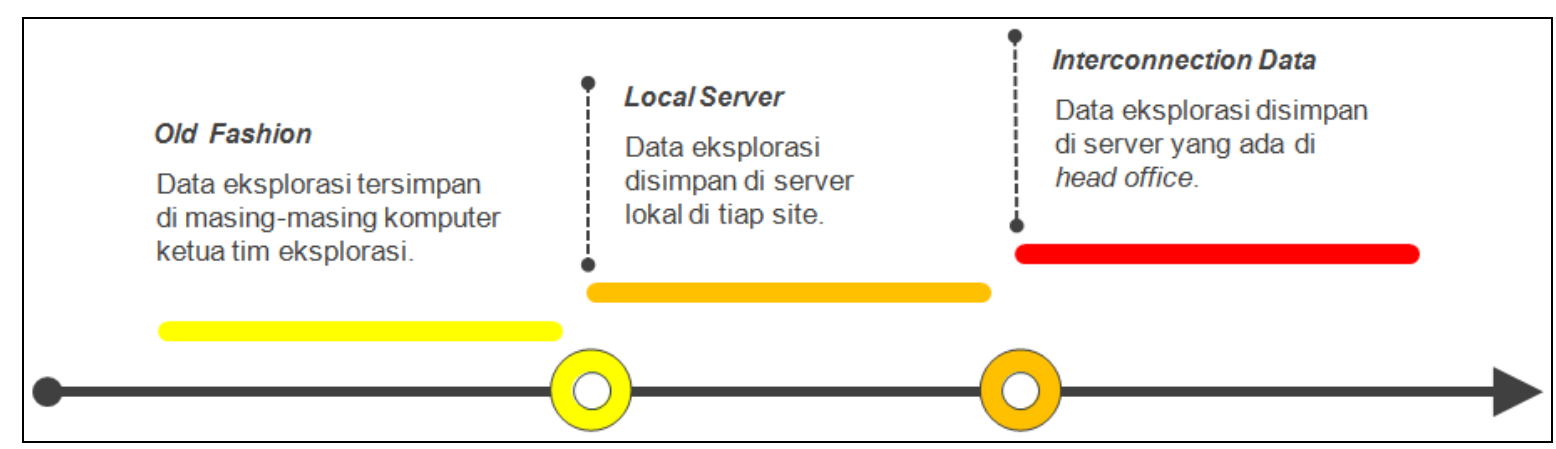

Gambar 7. Perubahan Sistem Koneksi Data ANTAM Terhadap Waktu

Pada Gambar 7 dapat dilihat perubahan penyimpanan dan koneksi database. Sistem yang ada saat ini adalah database tersimpan di server yang ada di head office, namun data tersebut dapat diakses dari tiap server lokal dan komputer user di tiap site dengan tingkatan akses yang berbeda-beda untuk setiap user. Tingkatan aksesnya adalah mulai dari akses hanya untuk update database sampai dengan hak akses untuk menghapus data yang perlu untuk dihapus. Akses tersebut bisa dilakukan di tiap site dengan sistem interkoneksi data, sehingga tidak ada perbedaan versi database. Block model sumberdaya dan hasil estimasi sumberdaya untuk perolehan eksplorasi juga dapat dilihat oleh user yang berkepentingan tentu saja dengan tingkatan akses yang dimiliki.

\section{KESIMPULAN}

Sentralisasi lisensi perangkat lunak dan interkoneksi data yang dilakukan oleh ANTAM membuat distribusi data eksplorasi dan update block model sumberdaya tiap komoditas ANTAM yang tersebar dari Indonesia bagian Barat sampai bagian Timur tidak terkendala jarak dan waktu, khususnya untuk update block model. Hal tersebut dapat dilakukan kapanpun dan dimanapun, serta siapapun yang memerlukan dapat menggunakan lisensi software yang tersedia di server. Meskipun masih terdapat ruang untuk pengembangan sistem tersebut, namun poin utama dari sistem yang ada saat ini adalah mengenai keamanan aset ANTAM, yaitu aset database eksplorasi dan perangkat lunak.

\section{DAFTAR PUSTAKA}

Industry 4.0, tulisan diperoleh melalui situs internet: www.en.wikipedia.org/wiki/Industry_4.0.

Industry 4.0 And How Smart Sensors Make The Difference, tulisan diperoleh melalui situs internet: www.spectralengines.com/articles/industry-4-0-and-how-smart-sensors-make-the-difference.

Mengenal Revolusi Industri Dari 1.0 Hingga 4.0, tulisan diperoleh melalui situs internet: www.wartaekonomi.co.id/read226785/mengenal-revolusi-industri-dari-1.0-hingga-4.0.

What is Industry 4.0? Here's A Super Easy Explanation For Anyone (Bernard Marr), tulisan diperoleh melalui situs internet: www.forbes.com. 